\title{
ENGAGING WITH NATURE IN TIMES OF RAPID ENVIRONMENTAL CHANGE: VULNERABILITY, SENTIENCE AND AUTONOMY
}

\author{
Thomas Heyd \\ University of Victoria (BC), Canada
}

\section{Abstract}

Increasingly rapid environmental changes since the middle of the $20^{\text {th }}$ century pose a significant challenge for vulnerable human populations. North American Native people from the Northwest Coast, as many other indigenous populations around the globe, have conceived landscapes as sentient, and capable of responding to human action. The consequent "social responsibility" taken for landscape is explored in the context of vulnerability to rapid environmental change. The basis for respect that underlies this sense of responsibility, and its significance for addressing human vulnerability to nature's agency through more adequate practices of mitigation and adaptation, is discussed. It is concluded that we face an imperative to reconceive the agency of natural phenomena.

KEYwOrds: Agency, vulnerability, indigenous populations, respect for natural processes, sentience, autonomy.

\section{COMPROMETIÉNDOSE CON LA NATURALEZA EN TIEMPOS DE RÁPIDOS CAMBIOS AMBIENTALES: VULNERABILIDAD, SENTIENCIA Y AUTONOMÍA}

\section{RESUMEN}

Los cambios ambientales cada vez más rápidos desde mediados del siglo xx plantean un desafío importante para las poblaciones humanas vulnerables. Los nativos de América de la costa noroeste, como muchas otras poblaciones indígenas en todo el mundo, han concebido los paisajes como seres sensibles y capaces de responder a la acción humana. Aquí exploramos la consecuente "responsabilidad social" por el paisaje en el contexto de vulnerabilidad al cambio ambiental rápido. Se debate la base del respeto que subyace este sentido de responsabilidad, y su importancia para abordar la vulnerabilidad humana frente a la agencia de la naturaleza, a través de prácticas más adecuadas de mitigación y adaptación. Se concluye que enfrentamos un imperativo de reconcebir la agencia de los fenómenos naturales.

PAlabras Clave: «agencialidad», vulnerabilidad, poblaciones indígenas, respeto hacia los procesos naturales, «sentiencia», autonomía. 
Rapid environmental changes that may be disastrous for human populations should lead to appropriate precautionary measures. Not everywhere can the resources be found to address disastrous events with grand and costly engineering solutions, though. Nor are most events that bring about rapid environmental changes, such as large-scale storms, droughts, storm surges on low-lying coastal zones, extremely hot summers, earthquakes, and tsunamis, amenable to straightforward managerial or engineering solutions. Such solutions, moreover, may be problematic in various ways. For one thing, they can lull populations into a false sense of security regarding relatively "rare high magnitude events, during which the coping limits of the engineered structure might be breached", as Nick Brooks (2007) points out.

When high impact, natural events occur, such as floods, populations that do not generally expect such eventualities will be found unprepared. Furthermore, solutions, that are perhaps suitable for "normal floods" but not for the sort of event that occurs every 500 or every 1000 years, may lead to planning decisions that can turn out to be dangerous. Some municipalities may, for example, declare land in floodplains fit for construction on the basis of historically low risk expectations. This is the case in Greater Vancouver (Canada) where parts of the city, only protected by a system of dykes, are located in the floodplain of the Fraser River. In the light of such considerations it is imperative that, as individuals and as societies, we address basic questions, such as whether potentially disastrous events may be preventable or at least be mitigated. Here it is proposed that, in order to develop appropriate measures, it may be essential to consider how potentially problematic natural phenomena should be conceived. ${ }^{1}$

\section{ENVIRONMENTAL CHANGE, VULNERABILITY AND MODES OF ADAPTING}

Volcanic eruptions, earthquakes, and floods have always been potential threats to human well-being, but their effects tend to be limited to relatively circumscribed areas. ${ }^{2}$ As of late, global climate change has become an ever more critical issue, both for experts and for the general public (see the draft Fifth Assessment Report, IPCC, 2013). Foreseeably, the phenomena that characterize climate

${ }^{1}$ I fully acknowledge that certain events generally classified as natural, such as storms and floods, may have a considerable anthropogenic component. Nonetheless, so long as the non-human natural contribution to the event is most significant, I will, for simplicity's sake, speak of natural events, phenomena, or processes. So, while I wouldn't count the radioactive contamination of the environment following an incident at a nuclear power station, such as happened at Fukushima Daiichi nuclear power plant 11 March 2011, leading to releases of radioactive materials, I do treat storms, such as Hurricane Katrina (2005), which may partly be the result of anthropogenic greenhouse gases, as natural. (I realize that this is not a neat way of sorting out the world but, for further clarification, see Heyd 2007, ch. 9.)

2 But see, e.g., Burroughs (2005) on the capacity of "supervolcanoes" such as Toba, Hekla, or Thera, to alter climate worldwide and for considerable time spans. 
change will be an issue for all human beings, present and into the foreseeable future, since the warming of the globe is expected to bring about important, and relatively rapid, environmental changes in terms of desertification, thaw of methane bearing permafrost in Arctic regions, reduction of the size and number of glaciers, rising sea levels, ocean acidification, and so on, in many parts of the world. Consequently, reference to climate change may be useful in the survey of some generally relevant issues regarding human responses to rapid environmental changes.

Climate change has brought into wide circulation the terms "prevention", "mitigation" and "adaptation". It is a reasonable assumption -supported ever more strongly by climate change research, such as is brought together by the Fifth IPCC Assessment Report (IPCC 2013) - that human contributions to the current transformations of climate are of crucial significance. It is clear, however, that the delay in the effects arising from the release of greenhouse gases makes wholesale prevention of global climate change impossible any more. In light of this fact much recent policy discussion concerning human responses to climate change has been cast in terms of mitigation, on the one hand, and adaptation, on the other. For many countries, including many encompassed in the European Union, mitigation has become a major concern, while in Canada certain Provinces, for example, British Columbia (Government of British Columbia, Climate Action Plan, 2008) and Québec (Gouvernment du Québec, 2012) are taking the lead in developing policies intended to limit greenhouse gas emissions. Since it has become evident, moreover, that severe effects are going to be inevitable in many parts of the globe, including in the Vancouver region (see Sheppard, 2012, for example), adaptation increasingly is becoming an important complementary policy issue.

"Vulnerability" is a key term in the context of global climate change. It can be understood in various ways. As Barry Smit (2005) has noted, vulnerability is the product of distinct factors: exposure and sensitivity to exposure, on the one hand, and adaptive capacity or resilience to exposure, on the other. Neil Adger and Nick Brooks (2002) similarly propose that "vulnerability is not simply a function of exposure, but also of people's capacity to adapt to change. If the latter remains unchanged, increased exposure will lead to increased vulnerability." (29). In other words, given a certain driver of environmental change such as global warming, which can generate powerful storms, earth slides, droughts, flooding, and so on, vulnerability is a function not only of the objective physical characteristics of the environment, such as low-lying coastal areas, steep mountain terrain, and so on, but also of how ready people are to respond in an adaptive way to those drivers. ${ }^{3}$

Researchers on climate change processes have been discussing a variety of possible physical adaptations to manage such phenomena. In areas with low-lying lands close to the sea, such as in the delta region of Bangladesh, building breakwa-

${ }^{3}$ Given the diversity of socio-economic and political situations in which people find themselves, vulnerability varies on both individual and collective levels. (On how to think about vulnerability (also see Kelly and Adger, 2000). 
ters and extended embankments in order to prevent flooding, is being considered (Ahmed et al., 1999). Another way to absorb change is in economic and social terms. People in the North African Sahel region, for instance, have responded to increased droughts by diversifying land use, moving from irrigated cash crops to more enduring subsistence crops, and by emigration to nearby cities in order to supplement incomes (see Mortimore and Adams, 2001).

Despite their obvious importance, a focus on technological, socio-economic or managerial solutions may well perpetuate a "fix-it" approach, which, ultimately, may be insufficient to overcome the challenges we face. A more fundamental approach would go deeper into the cultural fabric that animates all aspects of our interactions with the environment. Thomas Homer-Dixon has proposed that in order to cope adequately with our present times of "constant change and surprise" demands a new attitude that requires "a prospective mind", a mind that "recognizes how little we understand and how we control even less." (Homer-Dixon, 2005, p. 28) This complements his earlier demand to fill what he calls "The ingenuity Gap" (title of the Homer-Dixon, 2000, book; also see Homer-Dixon, 2006). As 'business as usual' will not do he proposes that, to generate the physical, social, and economic transformations needed to reduce vulnerability to climate change, we ought to develop our sophisticated, human-specific, cognitive capacity to address and solve such problems.

Developing our capacity to generate ideas, and to apply them to practical situations, definitely constitutes an important ingredient in sharpening our coping capacities. But in order to confront the kind of situations that bring about rapid environmental change in an adaptive way also is a matter of acquiring appropriate ways of perceiving, and habits and practices that are suitable to the new situations at hand. The importance of such alternative ways of perceiving, and of appropriate habits and practices, can be illustrated in the context of outdoor activities. For instance, while cross-country skiing in mountainous terrain during spring weather one will sometimes face conditions that may result in an avalanche. Even though a highly developed ingenuity may be of use in such circumstances to devise strategies of avoidance or, in the worst case, tactics of remediation, such ingenuity may be insufficient if not accompanied by the ingrained precautionary habits and the relevant perceptual framework, such that circumstances are adequately assessed for their degree of danger.

Given that in contemporary urbanized societies people are largely divorced from the natural environment on which they depend, our ways of perceiving natural phenomena tend to be highly mediated. In order to grasp the possibilities of lowering vulnerability to rapid environmental changes it would be valuable to take note of the ways of perceiving and valuing, and corresponding habits and practices, of peoples who have been long-time residents of places that are subject to important drivers of environmental change. 
To illustrate the importance of cultural responses to natural phenomena, I introduce an account, which illustrates a way of perceiving the biophysical environment that is very different from the ways of perceiving prevalent in our own, contemporary, Western societies. ${ }^{4}$ The noted Canadian anthropologist Julie Cruikshank (2001 and 2002) writes about cultural responses to natural phenomena, in the northwest of North America, during a period of climate change prior to contact with Europeans, recounting some of the oral traditions about glaciers of the coastal Alaska Tlingit and the Yukon First Nations. She retells stories about glaciers that swallow up whole villages, but also points to the fact that glaciers served as a kind of "highway" that connected the interior of the continent with coastal areas. According to these oral traditions, glaciers are not inert, slowly sliding masses of ice but entities that pay attention and respond to human behaviours, such as speaking carelessly, spilling blood, making noise, or cooking with grease in their vicinity (Cruikshank, 2001, 385, 387, 388).

Cruikshank describes these peoples' way of conceiving the whole ensemble of entities, made up of human and non-human beings, including glaciers, by the term "sentient landscapes". This term takes note of the assumption that, from the perspectives of the Alaska Tlingit and Yukon First Nations, the land is not just inert matter but alive, and capable of something akin to perception and action. To conceive of a stretch of land as a sentient landscape means that its diverse animate and inanimate components are not treated as mere resources (or mere obstacles, as the case may be) for human use, but as legitimate and full counterparts to human beings.

To people who have not been raised in the cultural milieux where these stories originate, the concept of sentient landscapes, and the accounts on which it is based, may seem incredible, even if, as Michael Chase (2007) points out, "the notion of the earth as animate is old and persistent, from Plato and Aristotle to Lovelock's Gaia hypothesis." In any case, to focus on the divergence of the respective worldviews would be to miss the point. What is relevant in our context is that Cruikshank describes the type of relationship between people and land exhibited in these oral traditions as involving "social responsibility" arising from "the social nature of all relations between humans and non-humans, that is, animals and landscape features, including glaciers" (Cruikshank, 2001, 382). This approach to landscape, of course, is not unique to Alaska Tlingit and the Yukon First Nations but common to many peoples who have deep roots in their lands, including the Inuit and the Indigenous

${ }^{4}$ There are other relevant accounts, of course. See, for example, Brian Fagan (2000), who contrasts the responses to natural phenomena during climate change of Sahelian herders, South Africa's San, and South America's Moche, among others. 
people of the Russian North as well as the Mapuche and Quechua of South America's Andes mountain ranges, and the Australian Aborigines. ${ }^{5}$

What is the normative import of this type of approach to land? Cruikshank points out that this "local knowledge embedded in oral traditions" displays "commitment to an active, thoroughly positioned human subject whose behaviour is understood to have consequences." (Cruikshank, 2001, 391) In her analysis, the type of relationship displayed in these approaches to landscape underscores "the social content of the world and the importance of taking personal and collective responsibility for changes in that world." (Cruikshank, 2001, 391) The basis of this sort of responsibility is worth exploring further. ${ }^{6}$

\section{SELF-ORGANIZATION AND AUTONOMY}

It is common to make a distinction between two sorts of duties or moral responsibilities in ethics. On the one hand, one may speak of responsibility regarding something, such as the natural environment, which stems from duties to other human beings who may be benefited or harmed by how we interact with the natural environment. On the other hand, one may speak of responsibility to certain beings, such as natural entities, on the supposition that those entities may also have a good of their own. Interestingly, the notion of "social responsibility" for landscapes described by Cruikshank seems not to fall squarely into either type of approach. Social responsibility for landscape, as described by Cruikshank, crucially depends on the conceptualization of natural entities as active and responsive.

As I explain more fully elsewhere, responsibility to some entity minimally presupposes conceiving it as being structured in such a way that one can expect it to maintain its organization (at least for a time) in the presence of diverse forces (see Heyd, 2005). In this sense it is common in biomedical contexts to argue that the duty of medical staff to care for the well-being of their patients is a given, as long as the patients can continue functioning, at least at some level, but to accept that, in the case of brain death, there is a legitimate case for not continuing to keep patients "hooked" to machines since their capacity to maintain its organization as human beings has ceased.

In order to clarify what sort of self-organization an entity has to have as a necessary condition for any responsibility to arise with regard to it, it seems appropriate to speak of 'autonomy' in some sense (Heyd, 2005). The term "autonomy" may be apt here since it literally stands for being one's own law, or setting oneself

5 When I write of having roots I do not intend to differentiate between nomadic and sedentary peoples. Also see Brody (2001) on the deep connection to particular stretches of land that even hunter-gatherers, who generally are called "nomadic", have.

${ }^{6}$ See Heyd (2007) for a fuller view on responsibility for the natural environment in which people are enmeshed (especially ch 4). 
one's own law, and, hence, implies the capacity for organising one's self, even if all autonomy is relative, of course, since all beings are subject to some measure of influence or control by something beyond their own self.

Understood this way, to attribute autonomy to some entity means that it is not only organized in such a way as to maintain its unity and integrity (at least for a time) in the presence of a variety of forces, but that it may exert a systematic force on its environment, possibly actively but at least passively, through resistance to (actual or potential) influences. In other words, perceiving an entity as autonomous is perceiving it as capable of maintaining its integrity, and of being sufficiently unified and dynamically structured to be both source and target of systematically effective forces. ${ }^{8}$

According to this description of autonomy we certainly should grant that animals and plants are autonomous. ${ }^{9}$ Animals seek to perdure, defending themselves, as far as they can, against aggression and sickness. Plants have ways of nourishing themselves, of countering pests, and even of controlling the effects of physical damage through mechanisms that seal cuts that would otherwise make them lose sap. The case for conceiving glaciers, tsunamis, and weather patterns, such as tropical storms, as autonomous is more problematic.

Nonetheless, insofar as these entities and phenomena have systematic ways of affecting their environments, and their power is due to their specific kinds of integrity (evident by the difficulty in splitting these phenomena into their parts), they fit the pattern: All of these entities or processes may be organized sufficiently to maintain a certain unity over some time, and to show resistance to external forces. A snowflake that makes up part of a glacier, a drop of seawater moving up-shore, or a raindrop that constitutes part of a tropical storm, are all inoffensive when considered singly, but when constituting parts of particularly structured entities or phenomena, such as glaciers, flooding waters, or rainstorms, matters are otherwise. As such, glaciers, tsunamis, and tropical storms are best conceived of as 'emergent phenomena'. ${ }^{10}$ (Though it is not possible to develop this point here, we may think of these phenomena in terms of the Actant-Network Theory. ${ }^{11}$ )

Consequently, the idea of social responsibility for our interactions with natural entities posited by Tlingit and Yukon First Nations, according to Cruikshank's account, makes a lot of sense if the entities in question are understood as having a

7 Also see Prigogine and Stengers (1994) on self-organizing systems, and Maturana and Varela on autopoeisis. I thank Michael Chase for pointing out to me the relevance in this context, moreover, of Kaufmann (1995) and (2000).

${ }^{8}$ I thank Mark Woods for helping me clarify these points. He suggests that the autonomy of nature "contrasts with obedience: wild things are autonomous because they have not changed to adopt the imposed will of another. We can also think of autonomy in terms of authenticity: being self-expressing, self-actualizing, or self-realizing".

9 But see Kant (1993) for giving a sense to the term "autonomy" that makes autonomy a property that exclusively may characterize human beings.

${ }^{10}$ See Holland (1998). I owe this reference to Michael Chase.

${ }^{11}$ See, e.g., Latour $(1987,2005)$. 
certain capacity for autonomy, as here described. Social responsibility in relation to natural entities becomes most relevant in the present of 'extreme' events, disastrous for human beings. There presently is considerable research being carried out on the impact on behaviour and cultural perceptions following people's experience of disastrous natural events (Torrence and Grattan, 2002; Blaikie et al., 1994). Apparently, such events typically will remain salient in a society's cultural memory if the elapsed time span does not go beyond one lifetime. This seems to be confirmed among some populations living in Papua New Guinea and the Solomon Islands, for example, with regard to awareness of the signs of impending tsunamis and volcanic eruptions (Davies, 2002, 37-38). Such 'extreme' events are seen as having a certain self-organization, which may lead to a feeling of respect for such phenomena, and consequent adaptive behaviours.

Such cultural perceptions may be oriented toward particular types of crisis situations, leading to particular coping behaviours, such as seeking high ground and ringing the alarm upon the recognition of the signs of impending events such as tsunamis. Other adaptive behaviours may be directed more toward the long term, such as the permanent relocation of villages or cities (Davies, 2002, pp. 39-40). ${ }^{12}$ Sometimes the respect generated by the recognition of the autonomy of natural phenomena may lead to more indirectly adaptive behaviours, such as the creation of myths and the establishment of taboos about occupying certain areas of the land (Lowe et al., 138). In those cases the concrete cultural memory of the disastrous effects of the event may become lost but not before leading to an adaptation that exhibits recognition of the power of these natural phenomena through habitual, ritual, or mythical means. So, although certainly not universally true, when people have been repeatedly exposed to phenomena that have sufficient self-organization to act in a unitary, possibly harmful way, one significant adaptation that people adopt seems to be the development of a kind of recognition of agency in these phenomena.

\section{LOWERING VULNERABILITY THROUGH RESPECT}

Suffice it to say that respect for natural phenomena may be of at least two sorts. On the one hand, people may feel compelled to respect some other being or process because of the perceived need to take care of themselves, as a mode of selfprotection or precaution (if the effects that such phenomena and processes may have on their surroundings are taken to be significant). This is the sort of respect that we ordinarily speak of when we say that we need to "respect" the weather conditions when we travel in the high country or in Canada's winter, for instance. Similarly, people who have experienced a volcanic eruption or an earthquake may develop a respectful attitude toward volcanoes and areas near geological fault lines, respectively.

12 Also see Fagan (2000) on the Moche relocation of their capital. Incidentally, not all adaptive behaviours need to constitute 'adaptations', in the sense of preparation for significant events. 
On the other hand, when the phenomena in question are conceived of as having such integrity and capacity to act that they mirror -even if only up to a point, our human capacity for maintaining integrity and for acting on the world- another form of respect also may seem relevant. ${ }^{13}$ This kind of respect is less a matter of taking care of ourselves than of allowing these other phenomena sufficient space and time to express their self-organization. This is the sort of respect that we ordinarily accord fellow human beings who need quiet space and time to study or sleep, which leads us to take precautions so to avoid making noise, for example. More grandly, such respect is expressed in moral injunctions, such as to always treat humanity as an end and never as mere means (see Kant, 1993), by which he means among other things that we ought to leave as much space for the expression of the other as we do for the pursuit of our own goals This sort of respect may arise from a perception of common fates, which, in combination with a sense of community or conviviality, may lead to conscience and moral sense (also see Heyd, 2007, ch. 2.).

"Social responsibility" for changes in the landscape, as described in Cruikshank's account, seems to arise from a combination of both of these kinds of respect. Insofar as natural phenomena can cause us trouble, we may want to take precautionary steps, and, insofar as the natural environment is seen as constituted by entities that are self-organized enough to resemble us in relevant ways, we may want to establish something akin to social relations with them. ${ }^{14}$ This need not be seen as anachronistic anthropomorphisation of the natural world if we do not attribute sentience to it but only a very limited sense of agency.

Michel Serres (1990/1995), for example, argues that the situation of human beings in relation to the rest of nature calls for a new "natural contract", a contract analogous to a social contract among human beings. This would be an agreement between human beings and the rest of nature such that the parties to the agreement can co-exist, and possibly even flourish each in its way, effectively requiring restrictions on the degree of human interference with nature. Such a contract would manifest a similar kind of respect for natural phenomena as is referred to by Cruikshank when she speaks of social responsibility for land.

In Serres' analysis, the consequences of our failure to agree on a "natural contract" in modern times have (mis)led human beings into activities that contaminate the natural environments with pollutants such that, ultimately, "natural services" of the sort taken for granted up to the present (clean water, clean air, productive land,

${ }^{13}$ It is notable that there may be good adaptive reasons for our tendency to anthropomorphize diverse entities and processes in the natural environment. See Burroughs. Phenomenologically it makes sense to take a moral perspective with regard to those beings that resemble us because we can empathize and sympathize with them. This does not mean, however, that our capacity for respecting other beings necessarily is limited to those that resemble us, as is evident in the case of respect for human beings of diverse types, all of whom necessarily fail to resemble each of us in some ways.

${ }^{14}$ It is notable that the feeling of respect and sense of responsibility may well arise with regard to phenomena and processes that one may not suppose capable of intentionality, understood as the capacity for making outright choices among possible courses of action. 
and so on) are increasingly vanishing. A natural contract would seek to limit human activities in such a way that the flow of natural services may continue undiminished for present and future generations. In short, a natural contract would demonstrate something like social responsibility for the condition of the natural environment insofar as it expresses respect for phenomena that seem akin to us in their apparent capacity to act, to which we may be vulnerable. ${ }^{15}$ Attention to vulnerability is especially relevant in situations in which natural forces may potentially transform landscapes in rapid ways that are catastrophic for human (and other living) beings. One way to think of human vulnerability may be as a function of the attention given to the autonomy of significant natural entities and processes in our environment.

As noted, vulnerability depends not only on exposure to hazards but also on readiness in the face of drivers of potentially harmful change. The recognition of the relative autonomy of certain natural phenomena and processes, though, may lead to respect, which can contribute importantly to adaptive capacity. As already noted, applied to the relation of human beings to their natural environment, respect may be conceived in at least two ways corresponding to the two ways discussed above: on the one hand, in terms of taking care of ourselves while, so to say, "in reach" or in the effective sway of those phenomena and processes, and, on the other hand, in terms of granting those natural phenomena sufficient "elbow room" (i.e., space and time) for their expression in our environment.

The idea of lowering human vulnerability by respecting natural phenomena and processes in this double sense has already been well understood by some environmental managers. Instead of trying to control rivers and the impact of the sea by raising levees or building more and higher sea walls, for example, some experts argue for the rehabilitation of deltas and polders as flood retention areas for rivers, and for the restoration of mangroves and coastal forests in the case of threatened coastal areas, respectively. Lowering vulnerability by taking note of the self-organization of natural phenomena in such ways may lead to the development of policies that lower vulnerability, both at the individual and societal level.

It is true, of course, that individuals may only have limited ability to move house or change the conditions in which they gain their livelihood. Nonetheless, as long as society makes certain material resources and know-how available, a lot of steps can be taken to adapt one's private space and one's workplace surroundings to potential environmental hazards. For example, in flood prone areas people have raised their houses or moved to upper stories (Climate Proofing, 2005). In earthquake

15 It may be objected, of course, that nature cannot enter into contracts since, as a whole, it lacks the capacity either to sign nor to commit and deliver on them. This is a significant worry, though it may be addressed by noting that this conceptual device would be effective even if merely understood in a fictive way: the key is that, if people commit to certain actions as if nature could deliver on its, a number of worrisome effects on us would diminish and might be corrected (e.g., the rate of global warming would diminish if we agreed to limit emissions of greenhouse gases -as if we had agreed with nature to do so). 
zones they reinforce buildings and firmly attach objects (such as bookshelves) to walls to prevent that they become hazards.

At the societal level, furthermore, the recognition of the power of natural phenomena means not subjecting populations to unnecessary risks, and making the material, social and informational infrastructures available that can help individuals and communities address natural phenomena that may potentially be hazardous to them. Practically this may mean making it possible for people to relocate away from high to low risk areas, to take a proactive approach regarding environmental changes that can be expected due to geological or geographical causes (e.g., earthquakes in areas with fault lines, floods in floodplains) by facilitating appropriate building standards and by regulating the use of suitable building materials, and so on. ${ }^{16}$

\section{CONCLUDING COMMENTS}

Rapid environmental change invites us to reflect on vulnerabilities and the ability to address natural phenomena appropriately. Confronting such changes effectively and responsibly certainly requires scientific research in order to understand natural processes, and the application of our ingenuity to come up with appropriate physical and socio-economic modifications to our environment and our societies. Decreasing vulnerability and strengthening resilience, however, are, moreover, grounded in larger, more encompassing, cultural matrices.

Based on the analysis of the notion of social responsibility for changes in the world introduced by Cruikshank, I have suggested that vulnerability, in a more general sense, be understood, in part, as a function of the conception of natural phenomena, held by individuals and societal decision makers, and of the values associated to those conceptions. As Cruikshank notes, "our human ability to come to terms with global environmental problems will depend as much on human values as on scientific expertise" (Cruikshank, 2001, 390). Insofar as the recognition of autonomy of natural phenomena may lead to adaptive behaviour and policies, we urgently need to promote their recognition as autonomous actants. ${ }^{17}$

Reviews sent to author: 12 April 2018

Revised paper accepted for publication: 26 July 2018

${ }^{16}$ For a list of possible steps that both individuals and society in general could take with regard to climate change, see Dauncey (2001). On historic and prehistoric human responses to powerful environmental impacts that did, or could have, amounted to catastrophes for human societies, see, for example, Leroy (2006), and Diamond (2006).

${ }^{17}$ For further development of the topic of respect for, and appreciation of, landscapes and nature, see Heyd (2007) and Heyd (2013). I am grateful to Edward Butterworth, Tony Berger, and Jutta Gutberlet for attentively reading this chapter, and providing me with useful comments. I am also indebted to Nick Brooks and Michael Chase who have made a number of excellent suggestions for improvements of this version of this essay. 


\section{WORKS CITED}

Adger, Neil and Brooks, Nicks: "Does global environmental change cause vulnerability to natural disaster?" Natural Disaster and Development in a Globalizing World. Ed. M. Pelling. London, Routledge, 2002. 19-42.

Ahmed, Ahsan Uddin, Alam, M. and Atiq Rahman, A.: "Adaptation to climate change in Bangladesh: Future outlook". Vulnerability and Adaptation to Climate Change for Bangladesh. Eds. Huq, S.Z. Karim, M Asaduzzaman and F. Mahtab. Dordrecht: Kluwer, 1999. 125-43.

Blaikie, P., Cannon, T., Davis, I. and Wisner, B.: At Risk: Natural Hazards, People's Vulnerability, and Disasters. London, Routledge. 1994.

Brody, H.: The Other Side of Eden, Hunters, Farmers, and the Shaping of the World. New York, North Point Press, 2001.

BRooks, Nick: Personal correspondence, 24 July 2007.

Burroughs, William James: Climate Change in Prehistory: The End of the Reign of Chaos. New York, Cambridge University Press, 2005.

Chase, Michael: Personal correspondence, 22 July 2007. Climate Proofing: A Risk-Based Approach to Adaptation. Manila, Asian Development Bank, 2005.

Cruikshank, Julie: "Glaciers and climate change: Perspectives from oral tradition.” Arctic54.4. (December 2001): 377-93.

Cruikshank, Julie: "Nature and culture in the field: Two centuries of stories from Lituya Bay, Alaska." Knowledge and Society (Research in Science and Technology Studies: Knowledge and Technology Transfer. Ed. Marianne de Laet. Vol. 13. Amsterdam, JAI/Elsevier Science, 2002. 11-43.

DaunCey, Guy: Stormy weather: 101 solutions to global climate change. Gabriola Island, B.C., Canada, New Society Publishers, 2001.

Davies, Hugh: "Tsunamis and the coastal communities of Papua New Guinea." In Natural Disasters and Cultural Change, Eds. Torrence, Robin and John Grattan. London, Routledge, 2002. 28-32.

Diamond, Jared: Collapse: How Societies Choose to Fail or Succeed. New York. Viking, 2005.

Fagan, Brian: Floods, Famine, and Emperors: El Niño and the Fate of Civilization, New York, Basic Books, 2000.

Gouvernement du Québec: Plan d'action 2013-2020 sur les changements climatiques 2012. http:// www.mddefp.gouv.qc.ca/changements/plan_action/pacc2020.pdf (accessed 9 October 2013).

Government of British Columbia: Climate Action Plan. 2008. http://www.livesmartbc.ca/attachments/climateaction_plan_web.pdf (accessed 9 October 2013).

Heyd, Thomas (Ed.): Recognizing the Autonomy of Nature: Theory and Practice. New York, Columbia University Press, 2005.

Heyd, Thomas: Encountering Nature: Toward an Environmental Culture. Aldershot, U.K., Ashgate, 2007.

Heyd, Thomas: "Landmarks of the sacred in times of climate change climate justice, icons, and policy" in Bergmann, S., Studies in Religion and the Environment/Studien zur Religion und Umwelt. Münster-Hamburg-Berlin. LIT Publishing. 2013. 
Holland, John: Emergence. From Chaos to Order. New York, Basic Books, 1998.

Homer-Dixon, Thomas F.: The ingenuity Gap. New York, Knopf, 2000.

Homer-Dixon, Thomas F.: "Adaptive Capacity and Resilience: How to Meet Challenges from Climate Change". Introduction to Climate Change: Impacts \& Adaptation, session. C-CIARN (Canadian Climate Impacts and Adaptation Research Network) Conference, London, Ontario, 1 June 2005. 2005.

Homer-Dixon, Thomas F.: The upside of down: Catastrophe, creativity and the renewal of civilization. Toronto, A.A. Knopf, 2006. IPCC, Fifth IPPC Assessment Report; <http://www.ipcc.ch/> (accessed 6 October 2013).

JiCKLING, Bob. (Ed.): "What is a good way to teach children and young adults to respect the land? A panel discussion". Transcript. A Colloquium on Environment, Ethics, and Education: Whitehorse, Yukon, Canada, July 14-16, 1995 (proceedings). Arts and Science Division, Yukon College, Whitehorse, Yukon, Canada, 1996, 32-48.

KANT, Immanuel: Grounding of the Metaphysics of Morals. trans. by James W. Ellington.Indianapolis, Hackett, 1993.

Kaufmann, Stuart A.: At home in the universe. The search for the laws of the self-organization and complexity. New York/Oxford, Oxford University Press, 1995.

Kaufmann, Stuart A.: Investigations. New York/Oxford: Oxford University Press, 2000.

Kelly, P.M. and Adger, W.N.: "Theory and practice in assessing vulnerability to climate change and facilitating adaptation". Climatic Change. 47. 2000. 325-352.

Ingold, T.: "Introduction to Culture". Ingold, T. Ed. Companion Encyclopedia of Anthropology, Humanity, Culture and Social Life. Routledge, 1994.

Latour, B.: Science in Action: How to Follow Scientists and Engineers Through Society. Milton Keynes: Open University Press, 1987.

Latour, B.: Reassembling the Social: An Introduction to Actor-Network-Theory. Oxford: Oxford UP, 2005.

Leroy, Susanne: "From natural hazard to environmental catastrophe: Past and present". Quaternary International. 158.1. December 2006.

Lowe, D.J., Newnham, R.M. and McCraw, J.D.: "Volcanism and early Maori society in New Zealand". Torrence, Robin and Grattan, John. Eds. Natural Disasters and Cultural Change, London and New York, Routledge, 2002. 126-61.

Maturana, Humberto, Varela, F., Cohen, R.S. and Wartofsky, M.W. (Eds.): Autopoiesis and Cognition: the Realization of the Living. Boston Studies in the Philosophy of Science. Vol. 42. Dordecht: D. Reidel Publishing, 1973/1980.

Mortimore, M. and Adams, W.M.: "Farmer adaptation, change and 'crisis' in the Sahel". Global Environmental Change. 11.1. 2001. 49-57.

Prigogine, Ilya and Stengers, I.: Order out of Chaos: Man's new dialogue with nature. Toronto, Bantam, 1984.

Serres, Michel: Le Contrat naturel. Paris, François Bourin. 1990. In English: Serres, Michel. Elizabeth MacArthur and William Paulson. Trans. The Natural Contract. Ann Arbor, University of Michigan Press, 1995.

Sheppard, S.R.J.: Visualizing Climate Change: A Guide to Visual Communication ofClimate Change and Developing Local Solutions. Abingdon, UK: Earthscan/Routledge, 2012. 
SMit, Barry: "Where From and Where to: Climate Change Impacts and Adaptation Research and Practice". Introduction to Climate Change: Impacts \& Adaptation session. C-CIARN (Canadian Climate Impacts and Adaptation Research Network) Conference. London, Ontario. 1 June 2005. 2005.

Sulyandziga, Pavel and Vlassova, T.: "Impacts of climate change on the sustainable development of traditional lifestyles of the Indigenous People of the Russian North: Towards the development of an integrated scheme of assessment". Northern Review, 24 (Winter 2001). 200-207.

Woods, Mark: Personal communication. 2005. 